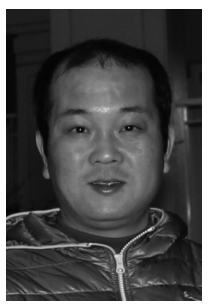

私の研究紹介 ${ }^{\dagger}$

稲 積 真 哉*

\title{
Brief Introduction on My Research
}

by

\author{
Shinya INAZumi *
}

この度，地盤改良部門委員会から推薦をいただき，会 員便りを執筆する機会を得ました。まだ未熟な教育研究 者ですが，これまでの略歴を交えて，私の研究を紹介さ せていただきます。

私は明石工業高等専門学校専攻科建築・都市システム 工学専攻を平成 10 年 3 月に修了し，同年 4 月より京都大 学大学院工学研究科土木工学専攻修士課程へ入学しまし た。さらに平成 12 年 4 月，同博士課程へ進学し，平成 15 年 1 月には京都大学から博士(工学)の学位を授与され ました。ここで, 私の学位論文は “Waste Sludge Barrier for Landfill Cover System” (廃棄物処分場のカバーシス テムへの污泥の利用に関する研究）であり，嘉門雅史京 都大学名誉教授によるご指導の下, 廃棄物処分場での降 雨の浸透を最小限に防止する機能を担うカバーシステム の積極的な導入を提案しました.

学位取得後の平成 15 年 2 月以降, 私は京都大学防災 研究所 21 世紀 COE 研究員として勤務, さらに, 平成 15 年 7 月より京都大学大学院工学研究科都市社会工学 専攻助手に採用され，同助教，平成 25 年 4 月より明石 工業高等専門学校都市システム工学科講師として採用さ れるとともに，同准教授として現在に至っています。こ れらの期間, 私は一貫して土木工学に立脚した地盤工学 (特に, 地盤環境工学ならびに地盤マネジメント工学), さらには地球環境学の分野に打いて, 各種廃棄物の処理 と建設材料への有効利用と環境影響評価，環境保全施設 に対する環境性能評価およびマネジメントに関する研究 に取り組んでおり，廃棄物の地盤材料としての再利用の 用途拡大ならびに廃棄物処分場で代表される環境保全施 設の合理的・経済的な環境マネジメント手法の確立に尽 力しています.

上記のような研究活動において, 私は平成 22 年度日 本材料学会賞 (学術奨励賞) ならびに平成 24 年度日本 材料学会賞（技術賞）を受賞させていただきました。そ れらの研究内容を以下, 簡単に紹介させていただきます.

私は, 各種遮水壁に使用する止水材について, 従来の 「塗る止水材」から「貼る止水材」へと使用概念を転換 し，止水材の用途・適用範囲の拡張を可能とするシート 状の止水材を開発しました。一般的に，建設分野で用い られる膨潤性止水材は, 熱可塑性エラストマーを母材と して, 高吸水性ポリマー, 充填材および溶剂等を配合し
た流動性のある塗料状の止水材であり，鋼（管）矢板の 継手遮水処理材として多用されています。このような膨 潤性止水材は水と接触すると膨潤し, 鋼 (管) 矢板継手 部の隙間（通水空間）を埋めることで, 継手箇所の遮水 を図るものです。この膨潤性止水材の膨潤機構は, 当該 膨潤性止水材に配合されている高吸水性ポリマーに依存 しています。ただし，高吸水性ポリマーは，海水のよう な塩類の存在する環境下において膨潤が阻害され, 膨潤 率が低下することが知られています。 なお，水温 $20^{\circ} \mathrm{C} の$ 条件下での現行の一般的な膨潤性止水材の膨閏率は, 淡 水浸漬で $20 \sim 30$ 倍, 海水浸漬で 5 〜 倍と言われてい ます。このように水質によって膨潤率には大きな差があ り, 海水条件下での膨潤率向上は重要な課題となってい ました。 また，近年では護岸工や河川締切工等とともに， 海面廃棄物処分場の遮水壁への適用に打いて，高い遮水 性と長期の信頼性が求められています。したがって，海 水条件下での膨潤率向上は必要不可欠であり，その性能 の向上により施工性の改善を図ることができ，且つ多種 多様な遮水工への適用拡大に繋がります.

海水環境下での膨潤率向上のため，私は配合される高 吸水性ポリマーの特性の一つであるエーテル化度に着目 しました。エーテル化度とは，高吸水性ポリマーの主骨 格であるグルコースユニットに存在する 3 つの水酸基を カルボキシルメチル基で置換した割合を表すもので，親 水性に影響を与える因子です。これを適切に制御するこ とで，淡水浸漬環境下での膨潤率を低下させることなく， 人工海水中で従来の 2 倍もの膨潤率を有する止水材を開 発することができました。この止水材を適用し, シート 状に加工した製品が「ケミカシート」です。このように して開発した「ケミカシート」は, 塗料型の従来止水材 に比べて施工性はもとより溶剤の周囲への拡散がなく, 塗布作業環境を著しく向上させることができました。ま た,「ケミカシート」の用途展開も進んで打り, 従来の塗 料状止水材では施工が困難であった平面一平面間の遮水 が可能となっています。加えて, その施工の容易さから 工期の短縮に大きく寄与できる画期的な止水材料です. さらには，ライナープレートや建設用鋼材の接合面の遮 水等に実績を積み重ねつつあり，今後，多目的膨潤性止 水材としてシート状の特長を生かした幅広い分野へ適用 が拡大してゆくものと大いに期待しているところです。

$\dagger \quad$ 原稿受理 平成 26 年 5 月 2 日 Received May 2, 2014 @ 2014 The Society of Materials Science, Japan

* 正 会 員 明石工業高等専門学校都市システム工学科 † 674-8501 明石市魚住町西岡, Dept. of Civil Eng., National Institute of Tech., Uozumi-cho, Akashi, 674-8501 